\title{
REFORMASIE EN ROMANISME- \\ 'N ONVERSOENBARE ANTITESE
}

Sonder twyfel het dit nodig geword om opnuut die aktuele vraag aan die orde te stel, of daar werklik uit godsdienstige gesigspunt 'n radikale verskil is tussen die Rooms-Katolisisme en die Reformasie wat in die sestiende eeu aangevang het. Dieselfde vraag sou ook anders gestel kon word: is daar waarlik 'n onversoenbare antitese, 'n onoorbrugbare kloof, tussen die Romanisme en die Reformasie; of, is 'n kompromis moontlik: kan Rome enersyds uit hoofde van sy grondleerstellings ooit tot ' $n$ vergelyk kom met die konsekwente Protestantisme, en durf hierdie Protestantisme andersyds sy eie tot so 'n mate prysgec dat dit op cenwording met die Roomse Kerk sou uitloop?

Hierdie vrae stel ons onder die diepe besef van die sondige verskeurdheid van die Kerk van Christus. En in hierdic gesindheid wil ons trag om, met afwysing van kwaadwillige polemiek en kleinlike aanval, 'n verkenning van die terrein en 'n nugtere ontleding van die situasie te onderneem. Ons stel ons ten doel om ' $n$ onomwonde en duidelike uiteensetting van sommige van die vernaamste en kenmerkendste leerstukke van die Rooms-Katolisisme te gee, egter met die opregte strewe om dit in die ware Christelike gesindheid en met billikheid teenoor die andersdenkende te doen. Dit gaan vir ons ook nie om persone soos Martin Luther of pous Pius IX 
nie; of selfs om die betrokke kerke nie, maar om die waarheid en die eer van God. In die verband word ook wel soms gesê dat insidentele verskille nie te veel klem most ontvang nie; maar die woord insidenteel kan seker nie met goeie reg gebruik word nie, want én die Rooms-Katolisisme én die konsekwente Protestantisme dra 'n sterk eenheidskarakter. Die verskilpunte is dus alleen van meer of minder belang na gelang hulle ' $n$ meer sentrale of periferiese plek in elke kader as geheel inneem.

Op hierdie stadium van ons betoog is dit ook wenslik om die vraag te stel of alle gesprek met Rome per slot van rekening nie nutteloos is, indien daar waarlik 'n prinsipiële verskil na godsdienstige inhoud en struktuur tussen die Reformasie en die Rooms-Katolisisme is nie. Hierop wil ons ontkennend antwoord. Openhartige gedagtewisseling het altyd sy nut: dit dien om misverstand uit die weg te ruim, en op die gebied van die godsdiens skep dit die geleentheid vir getuienis. Weliswaar kan geen mens of mensewoord die medemens se hart verander en die waaragtige geloof in sy binneste werk nie; maar wat by die mens onmoontlik is, is by God moontlik-ook deur middel van die woord selfs ,,uit die mond van kinders en suigelinge".

In verband met alles wat die naam van godsdiens dra, is die openbaringsbegrip van kardinale belang: dáár gaan die weë van alle godsdienste uiteen. En hier staan ook die Rooms-Katolisisme en die Protestantisme op die kruispad. Kenbron vir die godsdiens is volgens die Protestant die Heilige Skrif. Volgens die Rooms-Katoliek is dit die kerklike tradisie en die Skrif. Nog maar enkele weke gelede het die Roomse geleerde, prof. dr. C. Pauwels, O.P., dit weer bevestig in die maandblad Die Brug (April, 1955). Hy skryf o.a.: „Vir ons is die Heilige Skrif die Woord van God..... Ons verwerp slegs ,die Skrif alleen' ". Vir hom en sy medestanders is ,die Tradisie naas die Skrif" die gesaghebbende openbaring. Eintlik hét die opdieping van die waarheid uit die Skrif gedurende die loop van die eeue reeds plaasgevind en word dit tans net ontvou in die nouste verband met die ander gelykwaardige openbaringsbron, die tradisie.

Hierdie gelykwaardigheid is in sekere sin reeds heel vroeg erken. Die Vroeë Skolastiek is voorafgegaan deur 'n stryd tussen die twee beroemde skoolhoofde van die elfde eeu, t.w. Berengar van Tours en Lanfranc die latere aartsbiskop van Kantelberg. Berengar het die standpunt ingeneem dat die opkomende dialektiese metode nie ten opsigte van die Skrifwaarhede toegepas moet word nie, maar dat dit wel aangewend moet word om die egte van die onegte in die kerklike tradisie te skei. Sy opvatting is egter op verskeie sinodes verwerp. En hierdie veroordeling van sy beskouing het daarop neergekom dat die kerklike tradisie bokant kritiek verhewe is. 
en dat die dialektiese metode derhalwe slegs tot verdediging daarvan diensbaar gemaak moes word. Dit was aanleiding tot al die spitsvondighede van die Skolastiek om die teenstrydige uitsprake van die kerklike tradisie met mekaar te probeer rym.

Met betrekking tot hierdie tweërlei openbaringsbron speel die kerk die allerbelangrikste rol. Pous Leo XIII het hierdie rol in die encycliek Providentissimus Deus (1893) nader toegelig. Dit lui ,dat God die Skrifte aan die kerk toevertrou het" en dat die kerk dus die "volkome sekere leidsvrou en leermeesteres" is, sodat die ware sin van die Skrif ,die sin (is), wat geleer is en geleer word deur onse heilige Moeder, die kerk..... en dat dit dus aan niemand geoorloof is om die Heilige Skrif teen dié sin of ook teen die eenstemmige gevoele van die Vaders in te verklaar nie". Soseer is dit die geval dat die Roomse gesaghebbende Gerard Brom in sy werk Gesprek over de eenheid der kerk skryf: ,Zoals iemand om een goed staatsburger te zijn, het wetboek niet van buiten hoeft te leren, omdat hij het handhaven van de wet, aan het wettig gezag overlaat, zo kan iemand, om ' $n$ goed onderdaan in het Godsrijk te zijn, het onderzoek van de Schrift missen wanneer hij heel de Openbaring aanneemt, die de kerk hem waarborgt. (Gesiteer deur dr. G. C. Berkouwer, Conflict met Rome, p. 44). Die eiendomlike van die Skrif word dus misken en die persoonlike ondersoek van die Skrifte, waar die Protestant juis sy sieledors gaan les, oorbodig geag. Dit verbaas 'n mens dan ook nie dat Rome nie net die prioriteit nie, maar ook die primaat van die kerk bokant die Skrif handhaaf. Die argument dat die kerk vóór die Skrif bestaan het en dus voorrang moet geniet, is bekend genoeg; maar hierby verloor Rome uit die oog dat God Hom reeds in die staat van regtheid aan die mens geopenbaar het.

By Rome is egter ook ' $n$ veel dieper oortuiging aanwesig vir sy verheffing van die kerk bokant die Skrifopenbaring, t.w. die grondleerstelling dat die kerk ,de voortgezette vleeswording van de hemelse Heer" is. (Aldus Grossouw, aangehaal deur Berkouwer, p. 30-31). 'n Volstrekte vereenselwiging van Christus met die kerk in alle opsigte is egter uit die aard van die saak 'n onmoontlikheid, en dit wil Rome ook nie te kenne gee nie. Maar hoewel daar ook nog onder Roomse geleerdes verskil bestaan oor die sogenaamde Corpus Christi-teologie hou hulle almal vas aan die grondidee van die voortsetting van die vleeswording in die kerk.

Teen hierdie gedagte van die voortgesette vleeswording van Christus in die kerk het die Reformasie in verset gekom, omdat dit die grense tussen Skepper en skepsel, tussen Christus en die gelowiges as sy mistieke liggaam uitwis. Die feit en werklikheid van die geestelike gemeenskap wat deur die 
Heilige Gees tussen die verhoogde Heiland en die gelowiges gewerk en instandgehou word, die unio mystica, het die kerke van die Reformasie steeds bely, maar dan met besliste verwerping van alles wat sweem na konsubstansialiteit. Die Westminster Confession gee byvoorbeeld op voortreflike wyse uitdrukking aan ons Calvinistiese nagmaalsbeskouing in al sy diepsinnigheid: „Worthy receivers outwardly partaking of the visible elements in this sacrament, do then also inwardly by faith, really and indeed, yet not carnally and corporally but spiritually receive and feed upon Christ crucified, and all the benefits of his death: the body and blood of Christ, being then not corporally, in, with, or under, the bread and wine; yet as really, but spiritually, present to the faith of believers in that ordinance, as the elements themselves are to their outward senses" (Hf. 29, paragraaf 7).

In sy buitengewoon aktuele werk waarna ons reeds verwys het, vestig dr. Berkouwer die aandag daarop dat die liturgiese beweging, waarvan prof. G. v.d. Leeuw die vader is, 'n ,sterke verwantskap met de Roomse visie op de voorzetting der incarnatie" vertoon (p. 289). Dit blyk dan ook baie duidelik uit die onderhawige literatuur. Volgens genoemde outeur skryf W. H. v.d. Pol byvoorbeeld in Handboek voor den eredienst in de Ned. Herv. Kerk, wat saamgestel is deur die „,Liturgische Kring”, dat die inkarnasie van Christus sig ,,voortzet in de kerk van Christus, waar het bij voortduring nieuwe vruchten draagt in het leven der Heiligen" (p. 234). Dit wil egter nie sê dat die Liturgiese beweging die Roomse inkarnasieteologie heeltemal onkrities aanvaar nie. Berkouwer wys dan ook op die volgende verklaring van Van der Leeuw: ,Ik heb nog nooit in mijn leven de minste neiging bespeurd om mij op weg na de Roomse kerk te begeven" (a.w., p. 292, verwysing no. 34). Maar ten spyte hiervan skryf Berkouwer tog: „.... een incarnatie-theologie is niet in de Reformatie, maar in de Roomse theologie consequent" (ibid.) En hierdie woorde moes hy as eerlike vorser skryf, omdat dieselfde grondgedagte, nl. die van die voortgesette vleeswording van Christus in die kerk, ten grondslag van beide die Roomse opvatting en die van die liturgiese beweging lê. Dit blyk so duidelik uit hierdie beweging se nagmaalsbeskouing, waar die Verbondsmaal die tipies-Roomse karakter van 'n offermaal kry. Geen wonder dat daar sterk reaksie teen die stroming in die Ned. Herv. Kerk self ontstaan het nie: ,Zo merkt byvoorbeeld Van Oyen op: ,Er is in dit alles een diepe verwantschap met het catholisisme'. Waar blijft-zo schrijft hij-het eenmaal volbrachte zoenoffer van Christus: het hapax (éénmaal) van Hebreën, dat het altaar hierbeneden voorgoed naar de Hemel heeft verplaatst?" (Berkouwer, a.w., p. 290). En ook prof. O. Noordmans verklaar in sy Liturgie ,dat het, verraad aan Christus’ zou 
zijn, weer een eredienst met een altaar en offer in de gemeente op te richten" (idem, p. 293). In die heel jongste verlede het A. G. Luiks in Nederland gepromoveer op 'n proefskrif : Cathedra en mensa (Kansel en n'gmaalstafel). Die outeur het hom met die oog op hierdie dissertasie na NoordAfrika, die bakermat van die vroegste georganiseerde kerklike lewe, begewe. Sy bevinding was dat die kansel die beheersende plek in die kerkgebou ingeneem het. Die kansel is eers later in Europa, toe die sakrament onder Roomse invloed die prediking van die Woord verdring het, tersyde geskuif. „Daarom moet de kerkinrigting der protestantse sacramentalisten ook gezien worden als ontrouw aan de oude liturgie, waarin niet het avondmaal, maar uitgesproken de dienst des Woords het hart van de eredienst was". (Chr. Teeuwen in Geref Weekblad, 10e jaargang, nr. 40). Genoeg om ook ons as Protestante te waarsku teen insypeling van romaniserende invloede.

Ons het die onskriftuurlike Roomse gedagte van die voortsetting van die inkarnasie van Christus in die kerk as die diepste grond vir die verheffing van die kerk bokant die Skrif aangewys. Nou wil ons beklemtoon dat hierdie verheffing van die kerk sy verreikende konsekwensie gehad het en nog het. Dit is met name ook die grondsuil waarop die Roomse dogma van die onfeilbaarheid van die Pous as vicarius Christi, as plaasvervanger van Christus, rus. Op die Vatikaanse Konsilie van 1870 is die leerstuk met 'n groot meerderheid aanvaar. Dit lê neer dat wanneer die pous hom ex cathedra, d.w.s. in amptelike hoedanigheid, oor sake van geloof en sede uitlaat, hy met onfeilbaarheid spreek. Weliswaar het vooraanstaande teoloë soos Reusch en Döllinger hulle teen hierdie dogma verset en selfs die kerk verlaat. Ook J. C. Hefele, die kenner van die geskiedenis van die Roomse Kerk en insonderheid van die pousdom, het hom in sterke bewoordinge teen die voorgenome leerstuk uitgelaat. Hy het verklaar dat hy vir dertig jaar lank na die onfeilbaarheid van die pous gesoek, maar dit nêrens gevind het nie. Hy het selfs met offisiële bewysstukke aangetoon dat 'n pous soos Honorius I in sy leerbeskouinge gedwaal het en deur die sesde Ekumeniese Konsilie (680) veroordeel is. (Selfs 'n ander ,onfeilbare" pous, t.w. Leo II, het hom as ketter verklaar!' Die belangwekkende wat ons betoog betref, is dat selfs die onbetwisbare historiese bewysgronde teen die onfeilbaarheid moes plek maak vir die grondliggende dogmatiese opvatting van die voortgesette inkarnasie van Christus. Ook Hefele moes uiteindelik hiervoor swig.

Hierin is voorts die verklaring geleë vir wat anders so vreemd voorkom, t.w. dat intelligente opgevoede mense van die 20ste eeu, sonder enige skriftuurlike grond byvoorbeeld kan glo dat Maria ten hemel gevaar het; of dat 'n man soos Newman verklaar dat hy voor sy oorgang tot die Roomse 
Kerk die transsubstansiasie verwerp het, maar dat hy dit daarna geredelik aanvaar het! Wie eenmaal glo, blind glo ook teen die Skrifopenbaring en feite in, dat die menswording van Christus in die kerk voortduur, met name dat die pous die plaasvervanger van Christus is, en dat die Here in en deur hom onfeilbaar en met die hoogste gesag spreek, aanvaar ook alles wat die pous ex cathedra spreek onvoorwaardelik. Daar word wel soms verwys na die skuldbelydenis van pous Adriaan VI, wat deur die optrede van Luther in die engte gedryf is. Hy het onder andere bely: „We weten al te goed: ook aan de curie zijn sindslang veel verfoeilijke dingen geschied: misbruik in geestelyke zaken, overtredingen der geboden. Ja, dit alles heeft zich verergerd. Zo is het dan niet te verwonderen, dat de ziekte zich van het hoofd op de leden, van de pausen op de prelaten heeft overgeplant. Wij allen, prelaten en priesters, zijn van de weg der gerechtigheid afgeweken en sinds lang was er, geen enkele meer, die goed deed" (J. Brouwers, Protestant en Katholiek, deur Berkouwer aangehaal, a.w. pp. 83-4). Hierdie woorde druis egter geheel en al nie in teen die gedagte van die onfeilbaarheid van die pous nie: sy belydenis geld alleen die slappe tug en die verdorwe sedes, maar nie die leer nie. Selfs die hervormingsdekrete van die Konsilie van Trente, gedurende die Kontrareformasie, raak slegs die tugoefening en die scdes. Die leer is in geen opsig gerepudieer nie: daar is alleen gestreef om dit duideliker te stel. As daar 'n stelreël is wat vir die Rooms-Katoliek vasstaan, dan is dit: Roma locuta, causa finita est, as Rome gespreek het, is die saak afgehandel. Uit hoofde van sy vaste geloof aan die voortgesette vleeswording van Christus in die kerk en die gevolglike onfeilbaarheid van die pous as sy mondstuk mag en kan die Rooms-Katoliek die offisiële Roomse leer nooit in twyfel trek nie, en is daar geen sprake van dat hy met tersydestellinge van enige deel daarvan tot 'n vergelyk met die Protestant mag kom nie.

Ons het aan die begin gekonstateer dat die openbaringsbegrip, wat die godsdiens betref, sentraal staan, en dat ook die Romanisme en die Protestantisme hier op die tweesprong staan. Tans kan ons op grond van die voorafgaande ook verklaar dat die kerk volgens Rome in die persoon van die pous as vicarius Christi ampshalwe die beslissende woord onfeilbaar en met die hoogste gesag spreek. Hierteenoor staan dat vir die kerke van die Reformasie die Woord van God, en die Woord alleen, onfeilbaar is en met die hoogste gesag spreek. Hierdie teëstelling het Johannes Calvyn reeds helder ingesien en as volg geformuleer: „Die mag van die kerk is nie onbegrens nie, maar onderworpe aan Gods Woord, en as 't ware daarin ingesluit” (Institusie IV. 8, 4). En elders skryf hy: „Laat die kerk derhalwe 
nie wys wees uit sigself nie, en nie uit sigself iets bedink nie; maar laat hom die grens vir sy wysheid daar stel waar Hy ophou om te spreek" (Institusie IV, 8, 13). Vir ons is die sola Scriptura, die Woord alleen, nie net die hoogste gesag nie, maar ook die judex supremus, die hoogste regter.

Van Roomse kant word die vraag gestel: indien julle onderling verskil ook ten opsigte van die interpretasie van die Skrif, hoe kom julle dan tot 'n beslissing? Ons antwoord hierop lui as volg: Christus het beloof dat Sy Gees die kerk in die hele waarheid sou lei. Die kerkgeskiedenis bevestig dat Hy sy beloftes gestand gedoen het. Die Pinkstergemeente en vroeë kerk het uit die Woord van God geleef; en deur die besluite van die vroeë sinodes, soos die van Nicea (325), Konstantinopel (381) en Chalcedon (451) loop dieselde goudaar van die suiwere waarheid ooreenkomstig die Skrif. Hierdie konsilies of ekumeniese sinodes het hul beslissinge in gehoorsaamheid aan die Woord onder die leiding van die Heilige Gees geneem. Allengs het die ware kerk ontaard, soos ook die geval was met die kerk onder die Ou Bedeling. Nogtans het die Here nie toegelaat dat die poorte van die doderyk sy kerk heeltemal oorweldig het nie: daar bly steeds die seweduisend oor wat die knieë voor Baäl nie buig nie. Ook in die Middeleeue was daar diegene soos Ratramnus, Gottschalk en John Wiclif wat dit vir die waarheid opgeneem het. En in die verlengde van die waarheid het die Reformasie voortgearbei. Dus, die Skrif is sedert die eerste eeuc onder die beloofde leiding van die Heilige Gees op 'n bepaalde wyse geïnterpreteer: en hierdie interpretasie gee vir ons uitsluitsel. In laaste instansie is dit die sinode wat in geval van meningsverskil in onderworpenheid aan die Heilige Skrif en met inagneming van die leiding van die Heilige Gees deur die loop van die eeue die beslissing vel. In sy kommentaar op I Joh. 4:1 skryf Calvyn dat die Papiste hulle ook op konsilies beroep, maar dan op konsilies as sodanig sonder om ag te gee op die noodsaaklike onderwerping aan die Woord en Gees van God. En in Institusie IV, 9, 1 beklemtoon hy dat dit ,, die reg van Christus is, dat Hy voorsitter is van alle konsilies en geen mens in dié waardigheid tot metgesel het nie. En ek sê dat Hy eers dan voorsitter is, wanneer Hy die ganse vergadering deur Sy Woord en Gees bestuur." Sodanige vergaderings vrywaar die Protestant van indiwidualisme en subjektivisme en rig sy skrede op die weg van die waarheid. Per slot van rekening is daar geen ander vastigheid as die wat bewerkstellig word deur die waaragtige geloofsbinding aan Christus nie. Dit is dan ook volkome duidelik dat geen mens, ook nie die pous nie, maar alleen die opgestane Heiland deur die werking van die Heilige Gees ons voetstappe vas kan maak in sy Woord.

Die vraag ontstaan of dit moontlik is om vas te stel wat bepalend is 
ten opsigte van die openbaringsbegrip van Rome, en trouens nie net van sy kyk op die openbaring nie, maar van sy hele teologie. Is dit moontlik om uit te maak wát die besondere stempel op dié ganse denkstruktuur afdruk? Van Roomse kant is hierdie faktor deur Erich Przywara, die outeur van Analogia entis, aangedui as juis die analogia entis of synsanalogie tussen God en mens (cf. Conflict met Rome, pp. 308-9). Dit gaan hier nie oor die synsanalogie as sodanig nie, maar wel oor die Roomse duiding daarvan. Karl Barth wil wel van die synsanalogie, ook dié tussen God en mens, per se niks weet nie ( $K$. Dogmatik, I, l, p. VIII), maar is dan tog verplig om van die analogia relationis te spreek. Sonder twyfel handhaaf Thomas Aquinas en op voetspoor van hom die Neo-Thomisme die onderskeid tussen die oneindige Goddelike Syn en die eindige menslike syn; maar ten spyte daarvan vind die Roomse wysbegeerte en teologie in die geskape syn self van die mens ook ná sy sondeval die grond vir sy betrokkenheid op God. Hier skei die weë, en wie sy voet op die weg van die Romanisme geplaas het, gaan ook in alles daardie weg uit. In die lig hiervan wil ons by gebrek aan tyd slegs enkele kardinale Roomse leerstukke behandel.

Die eerste wat ons aan die orde stel is die Theologia naturalis of natuurlike godskennis soos dit by Rome voorkom. Thomas van Aquino het geleer dat die rede op die gebied van die natuur outonoom is, en dat die openbaring die terrein van die bonatuurlike oorheers. En tog omvat die bonatuurlike openbaring volgens hom ook 'n deel van die metafisiese wat deur die groot denkers onder die mense (soos die Griekse wysgere) self ingesien is. Op die Vatikaanse Konsilie (1870) is dan ook neergelê: „Dat God as die beginsel en doel van alle dinge, deur die natuurlike lig van die menslike rede vanuit die geskape werklikheid met sekerheid geken kan word" $(, \ldots .$. Deum, rerum omnium principium et finem, naturali humanae rationis lumine e rebus creatis certe cognosci posse"). Die verhouding tussen die openbarings- en redekennis het beroering onder die geledere van die Roomse geleerdes gebring. Verskeie name kom hier meteens in 'n mens se gedagte, soos Etienne Gilson en Maurice Blondel. Eersgenoemde, wat 'n geesdriftige voorstander van die Christelike wysbegeerte is, spreek onomwonde van die onvolledige en swakke karakter insonderheid van die redelike godskennis. Die kernvraag wat hulle besig hou, is of die God van die redekennis ook die God van die Skrifte is. Hieroor verbly 'n mens jou, maar die Roomse tradisie werp dan weer sy skaduwee oor dié ligpunt, terwyl hierdie filosowe uiteindelik tog maar weer die betreklike selfstandigheid van die redekennis verdedig. Hierteen teken nie alleen hedendaagse denkers soos Louët Feisser (De huidige verhouding tussen Theologie en Wijsbegeerte, pp. 27 v.v.) 
en Karl Barth heftig protes aan nie, maar reeds Calvyn het in sy kommentaar op Joh. 6: 46 verklaar: „Want die Majesteit van God is so verhewe dat die gedagtes van mense Hom nie kan bereik nie. Inteendeel, die godskennis wat versin word buite Christus om sal 'n dodelike afgrond wees." Wie die werke van Calvyn ken, weet dat hy in teenstelling met Barth die algemene openbaring veral op grond van Rom. 1:20 handhaaf, en tog keer hy hom, blykens die aangehaalde woord, soos Barth teen die Roomse beskouing oor die godskennis. Die verklaring daarvan is hierin geleë dat die hervormer die algemene openbaring as goeie gawe van God waardeer het, maar ook ingesien het dat die gevloekte werklikheid, met inbegrip van die mens, ' verdorwe openbaringsmedium is; en met name dat die verdorwe mens onmiddellik die lig van hierdie openbaring in duisternis verander. Daarom vermaan die apostel ook dat hy sonder verontskuldiging sal wees; en daarom lê die hervormer daar soveel nadruk op dat alle godskennis wat die mens versin, afgesien van die herskeppende genade wat daar in en deur Christus is, ' $n$ verdwaasdheid is. Alleen diegene wat in Christus herskape is na die beeld van God besit weer die ware kennis, ook die ware Godskennis. Hierin verskil ons as nasate van die Hervorming dan van die Rooms-Katolisisme dat dit kragtens sy synsbeskouing, wat te kort doen aan die radikaliteit van beide die verdorwenheid en die genade, reglynig konkludeer van die geskape (i.p.v. die herskape) menslike rede na die godskennis.

Vervolgens is dit nodig om die Roomse genadeleer atan 'n noukeurige ondersoek te onderwerp. „Wc staan hier”, aldus Berkouwer, „maar niet aan de periferie, maar in het centrum van het conflict, dat historische vorm $\mathrm{kreeg}$ in de reformatorische prediking van de rechtvaardiging door het geloof alleen" (a.w., p. 103). God het dit beskik dat Martin Luther aan die begin van die $16 \mathrm{e}$ eeu ten tonele getree het-daardie jong Augustynerhermiet in die klooster van Erfurt wat hom ten doel gestel het om die volkomenheidsideaal van die nominalisme te bereik. Van die hooggeroemde skolastikus Gabriêl Biel het hy geleer dat die mens hom deur eie inspanning en berou ontvanklik moes maak vir die boetsakramcnt en dientengevolge vir die geregtigheid. Steeds hoër eise het hy aan homself gestel, maar die gemoedsrus waarna hy so verlang het, nie gevind nie. „Ek het my gemartel tot bykans sterwens toe", so getuig hy self; en Melanchton verklaar: „Soms was hy in sy voorkomste aan 'n reeds gestorwene gelyk". En tog het die vrede nie in sy binneste ingedaal nie. Hy decl mee dat hy die woord geregtigheid selfs hoe langer hoe meer begin haat het, en dat ' $n$ gevoel van opstand by hom posgevat het omdat hy gemeen het dat God die onmoontlike van hom eis. Inderdaad, die weg van die Romanisme tot rus en vrede was die 
onmoontlike maar dit was nie die weg van God nie. Die Here ken sy tyd: terwyl Luther as hoogleraar aan die Universiteit van Wittenberg voorlesings oor die Heilige Skrif gehou het, het hy by die lees van die woorde: „Maar die regverdige sal uit die geloof lewe" (Rom. 1:17) die lig gesien. Hier is ,de religieuze natuur van de pistis (geloof) hersteld" (Bavinck, Geref. Dogmatiek, I, p. 541). Hier is die ketting van die valse geloofsbegrip as blote verstandelike toestemming van die waarhede wat die kerk voorgehou het, deurbreek. En metterdaad het Luther die geloof as allerpersoonlikste verhouding tot die lewende Christus, as kinderlike afhanklikheidstelling van sy Verlosser ervaar en die ware Christelike vryheid beleef. Langer kon hy toe ook nie swyg nie, maar het te velde getrek teen die Skolastiek en veral teen Thomas wat hom deur ,Aristoteles, die vernietiger van alle gesonde leer” laat mislei het. Sy leerstellings omtrent die vrye wil, die verdienstelikheid van goeie werke, ens., wat na twyfel en wanhoop voer, het hy in duidelike taal verwerp. „Daar”, so roep hy uit, ,, het ek Christus verloor; nou het ek Hom in Paulus gevind!"

Op voetspoor van Augustinus en Luther het die Reformasie teenoor alle vorme van Roomse sinergisme, van pretenderende medewerking en werkheiligheid van die kant van die gevalle en verdorwe mens, in die vrymagtige genade van God in Christus geroem. So skrywe Calvyn in sy verklaring op 1 Joh. 4:2 dat indien u die Roomse priester sou vra of hy die belydenis aangaande die Godheid en die mensheid van Jesus onderskryf, hy onmiddellik bevestigend sal antwoord. Maar dan lê hy u die verdere vraag op die lippe: „Sê my, priester van die kerk van Rome, wat bly daar van die skone belydenis aangaande die Middelaar oor in u kerk met sy leer van die vrye wil, van verdienstelike werke, van die voorspraak van die heiliges, ens?" Nie dat Calvyn niks van die goeie werke wil weet nie, maar dat die goeie werke by die Reformasie heeltemal 'n ander funksie as by Rome het: hulle is nie verdienstelik of medeverdienstelik tot verlossing nie, maar is in Christus deur God voorberei (Ef. 2:10); hulle is die gevolg, die vrug van dankbaarheid vir die volbragte Middelaarswerk. Daarom kon hy ook skryf: ,,So is dit duidelik hoc waar dit is dat ons nie sonder die werke nie, maar tog ook nie deur die werke geregverdig word nie" (Institusie III, 16, 1).

Teen hierdie Reformatoriese leer van die vrymagtige genade van God het Rome hom begryplikerwyse met alle mag verset. In die pouslike bul Exsurge Domine word 41 van Luther se stellinge as ketters veroordeel. Nadruklik word onder andere sy opvattings aangaande die vrye wil en die goeie werke verwerp. En op die Konsilie van Trente word die leer van die Reformasie met dieselfde skerpheid veroordeel. 
Ons hou hierby wel in gedagte dat van Roomse kant betoog word dat die Pelagianisme (d.w.s., die dwaalleer dat die mens onsondig gebore word, 'n volkome vrye wil ook ten goede het, ens.) op die sinode van Carthago in 418 veroordeel is, en dat selfs die Semipelagianisme (d.w.s., die dwaling dat die mens wel nie dood in die sonde is nie, maar tog krank is, sodat hy met die ondersteuning van die Goddelike genade die goeie kan doen) op die sinode van Orange in 529 afgewys is. Maar die volstrekte soewereiniteit van die genade word selfs hier nie gehandhaaf nie, waar die dubbele predestinasie wat Augustinus geleer het, verwater word-die predestinasie ten opsigte van die verworpenes word tot 'n blote voorkennis herlei-, en waar gewag gemaak word van die hulp en medewerking wat Christus skenk aan heilbegerige gedooptes, indien hulle self wil werk. Op die keper beskou erken Rome dat die natuur nie geheel en al verdorwe is nie, alleen maar: die genade is destyds deur die afwykendes, volgens Rome, ten gevolge van konnaturaliteit te naturalisties gedui.

Ten tye van die Reformasie is Rome deur ' $n$ teëstander van ' $n$ ander kaliber en met ander oortuigings gekonfronteer. Hierdie keer is alle nadruk juis op die vrymagtige genade gelê en nou openbaar Rome sy diepste wese deur die goeie wat daar nog in die natuur uit hoofde van sy geskapenheid is, te bely. Met beslistheid wys die kontrareformasie op die sinode van Trente dan ook die Reformatoriese belydenis af dat die vrye natuurlike wil heeltemal verlore gegaan en uitgedoof is. Hierby kon die gratia praeveniens (vóórkomende genade) aansluit, met dien verstande dat dié genade dan die eerste stoot gee aan die heilswerk, aldus Rome. (Die fout waarin die Semipelagianisme verval het, sou volgens Rome, wees dat die begin van die geloof aan die beslissing van die vrye wil te danke is). Die belangrike is dat die Romanisme steeds ' $n$ res van die menslike natuur wat nie verdorwe is nie in beskerming neem. Dit is wat Berkouwer , het anthropologisch optimisme" by Rome noem (a.w. p. 125) en wat hy tipeer as 'n aanknopingspunt met „ontologisch accent" (idem, p. 137). Hy gaan dan voort: ,..... terwyl in de reformatorische gedachtengang waarlijk alles is ingesteld op de,richting' van het ganze leven, wandelend naar God toe of van Hem af. In de reformatorische beschouwing ging het dus niet om een existentie-analyse, maar om het religieus aspect van de ganse gehandhaafde menselijke existentie" (idem, p. 137). Ons sou dit as volg wil stel: op reformatoriese standpunt is die mens geheel en al na natuur en wese verdorwe; maar ook toe die diepverdorwe verlore seun sy rug op sy Vader gekeer het, het hy deur die algemene genade van God mens gebly wat nog wis dat sy Vader bestaan, wat nog 'n Godsbewussyn gehad het, al wou hy nie aan sy Vader 
dink nie. In hierdie menswees wat in sigself heeltemal verdorwe is, maar wat deur die algemene genade van God tog instandgehou word en waarmee Hy deur dieselfde genade die Godsbewussyn-hoe ontaard dan ook alonlosmaaklik verbind, lê die aanrakingspunt vir die herskeppingswerk. M.a.w. die vrymagtige genade van God in Christus sluit direk by sy algemene genadewerking aan en herskep die hele verdorwe mens radikaal.

Hierdie opvatting verskil prinsipiëel van die Roomse, wat die soewereine herskeppende genade begrens deur 'n onverdorwe res in die natuur te aanvaar.

Andermaal het ons, wat die Roomse opvatting betref, by die synsbeskouing uitgekom wat, volgens die skerpsinnige Przywara, in selfwerksaamheid van die kreatuur in laaste instansie ook die onderhawige genadeleer bepaal (cf. Berkouwer, a.w. pp. 308-9).

Wie 'n bespreking van die vernaamste Roomse dogmas onderneem, moet ook oor die Maria-leer handel. Nie alleen is dit 'n sentrale leerstuk nie, maar dit ly ook geen twyfel nie dat die belangstelling in die Mariologie en die verering van Maria gedurende die afgelope eeu, d.w.s. sedert die amptelike afkondiging van haar onbevlekte ontvangenis in 1854, steeds toegeneem het. Soseer is dit die geval dat Bavinck sowat 40 jaar voor die dogma van die hemelvaart van Maria (1950) uitgeroep is, kon voorspel: „Zelfs de leer van hare hemelvaart is eene quaestie van tijd" (a.w. III, p. 262). En as 'n besadigde denker soos hy nie aarsel om daaraan toe te voeg ,De Mariolatrie verdringt bij Rome de ware, Christelijke Godsverering hoe langer hoe meer" (idem, p. 263), dan verdien dit ons ernstige aandag.

Vooraf wil ons daar nadruk op lê dat die Reformatore en hulle geesteskinders steeds met grote eerbied oor Maria gespreck het. Hoe kon hulle ook anders waar die engel haar begroet het met die woorde: „Begenadigde! Die Here is met jou; geseënd is jy onder die vroue". (Luk. 1:28). Maar dieselfde mense het luide protesstemme laat hoor teen wat hulle beskou as oorskryding van die grense van die kreatuurlike in verband met die Roomse verering van Maria en die gevolglike godslastering wat daarmee gepaard gaan. Hierby het dit die Protestantse teoloë nie ontgaan dat die RoomsKatolisisme verklaar dat die latreia of aanbidding slegs aan God toekom en alleen die hiperdouleia of buitengewone heiligesverering aan Maria toegebring word nie. Die vraag is egter of Rome ten spyte hiervan nie daadwerklik in mensvergoding verval het nie (cf. Bavinck, a.w., p. 263).

Die belangrikste punt in die geding is dié aangaande die aandeel van Maria by die middelaarswerk. As pous Benedictus XV byvoorbeeld in die encycliek Inter Sodalicia (1918) verklaar dat Maria met haar lydende en 
sterwende Seun gely het, en om aan die geregt gheid van God te voldoen, vir sover as d't haar aangaan, haar Seun geoffer het, en as hy skryf dat ' $n$ mens van Maria kan sê dat sy met haar Seun die menslike geslag verlos het, dan kom die Protestant in opstand hierteen. Van Roomse sy word daar dadel' $k$ geantwoord dat ons veroordeling op ' $n$ misverstand berus, t.w. dat ons as Protestante nie voldoende daarop ag gee dat $n$ 'ks wat van Maria geleer word ooit van haar Seun geïsoleer mag word nie. Daar is naamlik 'n organiese band tussen haar en haar Seun en op grond van hierdie onverbreekbare samehang kan die beskouinge omtrent en verering van Maria geregverdig word. Sy kan selfs "medeverlosseres" heet en kragtens haar bloedverwantskap met God die Seun het sy in ,een soort aanverwantschap" gekom met die Vader en die Heilige Gees, en is sy in die Goddelike familie opgeneem (Friethoff, soos deur Berkouwer aangehaal, a.w. p. 212). Hierteen moet ons egter opnuut beswaar maak, omdat hier onmiskenbaar 'n soort vermenging tussen die Goddelike en die menslike geleer word: die somatiese afstamming van Christus kan Maria nooit in enige soort ontologiese verhouding plaas tot Hom en die ander Persone van die Drieëenheid nie. Sulke opvattinge is bewus of onbewus deur die Roomse tradisie ingegee. En as daar dan tog 'n poging aangewend word om hulle Skriftuurlik te fondecr, dan staan die uitlegkunde geheel en al in die teken van die inlegkunde. Wanneer daar byvoorbeeld 'n beroep gedoen word op die moederbelofte en op die woorde van Maria: ,Hier is die diensmaagd van die Here. Laat dit met my gaan volgens u woord" (Luk. 1:38), dan druis die Roomse eksegese in teen die eenvoudige en klaarblyklike sin van die woorde. Immers, volgens Gen. 3:15 is dit Christus as dié saad van die vrou wat die kop van die slang vermorsel, en Hy alleen. En, die aangehaalde woorde van Maria spreek tog van haar onderwerping aan die Goddelike welbehae, en nie van 'n selfstandige wilsbesluit van haar kant wat haar'n deelgenoot makk aan die middelaarswerk nie.

Nie alleen mag Maria in geen opsig ,Middelares” of selfs „Medeverlosseres" heet nie, maar mag selfs nie vir haar die plek in die kerk ingeruim word wat die Skrif haar nie toeken nie. In die Pinkstergemeente neem sy nergens leiding nie en daarna word slegs een maal, en wel Gal. 4:4, indirek na haar verwys. En as daar dan tog ten spyte hiervan van Maria gespreek word as: „..... dochter des Vaders, bruid van den Zoon ..... Miterlöserin" (Bavinck, a.w. III, pp. 262-3), as kinders ook in ons eie vaderland die Salve Regina geleer word: „Wees gegroet, o Koningin, Moeder van barmhartigheid, ons lewe, ons soetheid en ons hoop....." (Katolieke Katechismus vir Suid-Afrika, p. 151), dan noop die eer van God ons om in 
verset te kom hierteen, en dan blyk dit tot watter eksesse 'n synsbeskouing kan voer wat die mens-ook die mens Maria-nie in al die dieptes van verdorwenheid aan die kaak stel nie.

Laat ons dan enersyds die waaragtige liefde ook jeens die Roomse as ons naaste koester, maar ons ook andersyds geen illusie omtrent Rome maak nie: die "Catholica" bly steeds dieselfde. Hoe sou hy ook in enige opsig kan verander sonder om ontrou te word aan sy eie diepste oortuiging dat hy die Goddelike waarheid onfeilbaar en met die hoogste gesag spreek? Daarom het Gerard Brom ook gewaarsku dat óns die hoop moet laat vaar dat die Moederkerk ooit iets van sy leer sal prysgee ten einde die eenheid met ons moontlik te maak. En as daar van Roomse kant van 'n „Brug”, gespreek word, dan is die stilswygende veronderstelling dat die brug vir eenrigtingverkeer bedoel is: terug na Rome!

Laat ons met volkome nugterheid vir onsself rekenskap daarvan gee dat die "moeder" Rome ons, haar „ongehoorsame kinders". sal probeer oorreed om terug te keer slegs solank as sy nie by magte is om ons te dwing om terug te keer nie. Die stelreël: „Cogite intrare!” (Dwing hulle om in te kom!) wat op die sinode van Carthago in 404 aanvaar is, is nog nooit en sal ook nie herroep kan word nie. Immers, dit is 'n wesentlike deel van die leer van Rome. As diẻ kerk die enigste ware kerk is wat bowendien steeds met onfeilbaarheid en dic hoogste gesag gespreek het, dan volg dit met onverbiddelike logika dat hy nie kan nie. Daarom het die groot dogmatikus van hicrdie kerk, Thomas van Aquino, in die 13e eeu geleer dat dic pous as die koning van die konings ook oor die swaardmag beskik, waarmee hy dic afvalliges kan dwing om terug te keer. In dieselfde eeu het die pouse Honorius III en Innocentius IV gedekreteer dat alle ketters uitgeroei moet word. In die $16 \mathrm{e}$ en $17 \mathrm{e}$ eeue is ons eie voorgeslagte wreed vervolg. En ons moet ons nie deur slagwoorde soos: „afgesaagd” en ,oordrewe” van koers af laat bring nie. 'n Gebeurtenis soos die massamoord op die Bartolomeüsnag (23 Augustus 1572) toe tienduisend Hugenote om die lewe gebring is, plaas ons voor die historiese werklikheid, en watter ontsettende werklikheid is dit nie! En so heilig oortuig was die pous dat hy en sy medestanders die wil van God volbring het dat hy die gebeurtenis feestelik gevier het, dic bekende loflied Te Deum laat aanhef het en 'n gedenkpenning laat slaan het. Ook in die 20ste ecu hou Rome aan die adagium: semper idem. In hierdie eeu is op gesag van die pous Die Institusie van Openbare Kerkreg gepubliseer. In deel II, p. 142 word verklaar: ,In hierdie eeu behoort die reg aan die Kerk om die uiterste strafmaatreëls, selfs die dood, toe te pas .... Terwyl die crvaring leer dat daar geen ander middel is nie, is die enigste al- 
ternatief die doodstraf. Want ketters verag uitbanning ..... Daar is geen ernstiger oortreding as kettery nie, en derhalwe moet dit met vuur en die swaard uitgeroei word. Dit is 'n Katolieke stelreël wat getrou onderhou moet word dat die uiterste straf nie alleen kan nie, maar ook moet toegepas word ten opsigte van hardnekkige ketters". Nou begryp u waarom ons geloofsgenote vandag in Spanje en Suid-Amerika aan vervolging prysgegee word en waarom Rome ook ons met die toepassing van die uiterste strafmaatreëls sal dwing om terug te keer sodra as hy kan!

Laat ons daar steeds helder bewus van bly dat ons hier nie net met akademiese kwessies te doen het nie, maar met die nakte werklikheid en wat nog meer sê: met sake wat die wese van die ware godsdiens raak. Ons is daagliks--en helaas besef ons dit selde!-_in 'n stryd om lewe en dood met Rome gewikkel-'n stryd waarin dit gaan om die handhawing van die Christelike godsdiens in al sy suiwerheid en van die eer van die Christus van die Skrifte. Kategories kom die woord tot ons: „So sê die HERE.....", en waar die Goddelike imperatief ons in die ore klink, sidder ons, maar daarvoor wil ons ook uit waaragtige liefde stry en selfs ons lewe aflê. En slegs met diegene wat voor die majesteit en gesag van diê Woord en dié Woord alleen buig wil ons en kán ons in Christus een wees.

F. J. M. POTGIETER.

Teol. Kweekskool, Stellenbosch. 